\title{
Influence of Spiral Nematodes (Scutellonema spp.) on Maize Performance and Growth under Natural Field Infestation in Mwea, Kenya
}

\author{
Samuel Maina (iD) and Rossa Nyoike Ng'endo \\ Department of Biological Sciences, University of Embu, P.O. Box 6-60100, Embu, Kenya \\ Correspondence should be addressed to Samuel Maina; samuelthaithi92@gmail.com
}

Received 10 February 2020; Revised 5 May 2020; Accepted 11 May 2020; Published 14 August 2020

Academic Editor: Anshu Alok

Copyright (C) 2020 Samuel Maina and Rossa Nyoike Ng'endo. This is an open access article distributed under the Creative Commons Attribution License, which permits unrestricted use, distribution, and reproduction in any medium, provided the original work is properly cited.

\begin{abstract}
Maize (Zea mays L.) is a significant food security crop in Kenya and it serves as the main source of nutrition and calories among the small-holder farmers. The overall maize yields per hectare have been fluctuating in the past few years posing a great risk to food security. Among the stress factors associated with maize yield loss include plant-feeding nematodes. In this regard, this study was conducted to evaluate the impacts of plant-parasitic nematodes specifically Scutellonema spp. under field conditions on maize performance in Mwea, Kenya. The field trials were laid out in a randomized complete block design with each treatment comprising of four replicates. The treatments included maize plots without nematicide (MPWN) and control plots treated with nematicide. The experiments were conducted in two trials. Soil samples were taken at a $0-20 \mathrm{~cm}$ depth at monthly intervals during 2018-2019. During the two trials, MPWN recorded significantly lower plant height and number of leaves per plant. Correlation analysis revealed a significant negative relationship between Scutellonema abundance with leaf area index, plant height, and number of functional leaves in MPWN during the 2019 trial. This implies that high population of Scutellonema perhaps has the potential to affect leaf area index, plant height, number of leaves per plant, which are aspects that in turn influence maize productivity. Therefore, holistic sustainable management practices to control Scutellonema spp. in maize fields such as use of organic amendments, resistant maize cultivars, and antagonistic organisms are crucial in order to alleviate negative impacts linked to Scutellonema infestation.
\end{abstract}

\section{Introduction}

Maize (Zea mays L.) plays an integral role in national food security in Kenya by providing 36\% and $65 \%$ of overall and staple food calories that are consumed, respectively $[1,2]$. The area occupied by maize production in Kenya declined slightly from 2.12 (million hectares) MHa in 2013 to $2.1 \mathrm{MHa}$ in 2014 [2]. Moreover, the overall maize yields per ha have been fluctuating in Kenya and also in other developing countries since the year 2010 [3]. Maize yield fluctuations are attributed to persistent biotic and abiotic constraints [4]. Previous studies have proposed several biotic constraints that affect maize yields which include plant-feeding nematodes such as lesion nematodes (Pratylenchus spp.), rootknot nematodes (Meloidogyne spp.), and spiral nematodes (Scutellonema spp.) [5-7].
Monitoring plant performance during different growth developmental stages provides valuable information in crop management. This information in combination with other relevant factors is of vital importance to farmers by helping them in implementing reliable and timely interventions [8]. Recently, it has been found that plant dynamics including growth and reproduction are strongly affected by interactions between plant roots and the microflora of ground such as plant-feeding nematodes, particularly at local spatial scales $[9,10]$. Previous reported literature showed that soil diversity and its flora can impact plant growth and performance in positive and negative ways, either directly through various mechanisms such as herbivory, symbiosis, and pathogenesis [11-13] or indirectly through predation of plant grazing organisms or fluctuations in the availability of soil nutrient [9]. Therefore, understanding such interactions 
between maize and parasitic nematodes can provide crucial information on their management and enhancement of crop productivity. It has been demonstrated that Scutellonema spp. is one of the ubiquitous polyphagous belowground herbivorous nematodes of economic importance to many food crops of economic significance including maize [14-17]. Bridge [14] reported that Scutellonema spp. feeds ectoparasitically on plant roots before invading the deeper cortical layers and becoming migratory endoparasites. However, such studies on interactions between plant root and belowground herbivores are scarce in Kenya despite the economic relevance of ground herbivores to crop productivity.

In order to understand the maize plants performance, this study assessed various growth parameters which included leaf area index, plant height, ear height, number of functional leaves per plant, and grain yield in plots under natural infestation by spiral nematodes particularly Scutellonema spp. whose economic importance on maize growth and productivity has not yet been ascertained in Kenya [5, 6]. Herein, we also looked at soil physicochemical properties, minimum temperature, and average rainfall so as to assist in understanding the prevailing conditions of the study site.

\section{Methodology}

2.1. Site Description. This study was performed in two trials in 2018 (October-January) and 2019 (January-April) at Nyangati, Mwea subcounty, Kenya (longitude $0^{\circ} 36^{\prime} 45.5^{\prime \prime} \mathrm{S}$ and latitude $37^{\circ} 21^{\prime} 18.0^{\prime \prime} \mathrm{E}$ ). The region is located in agroecological zone 3 of the lowland altitude at $1202 \mathrm{~m}$ above sea level. The soil type in the area is characterized as vertisols [18] and receives two rainy seasons per year, with long rains that average about $900 \mathrm{~mm}$ (from March to May) while short rains average to $800 \mathrm{~mm}$ (from October to November). The minimum temperature and the average rainfall recorded in the area during the study period are given in Table 1, whereas soil physicochemical characteristics analyzed at the site to a depth of $25 \mathrm{~cm}$ are shown in Table 2.

2.2. Experimental Design. The experiment comprised of two treatments consisting of control plots (treated with nematicide-Confidor WG 70 applied at the rate of 800 litres per hectare at planting) and maize plots without nematicide $(\mathrm{MPWN})$. The field trials were set in a completely randomized block design (CRBD) with each treatment consisting of four replicates. The size of each plot was $36 \mathrm{~m}^{2}$ $(6 \times 6 \mathrm{~m})$, and each plot and block were separated by $1 \mathrm{~m}$ and $1.5 \mathrm{~m}$ buffer zone, respectively. Two maize (Zea mays; variety Katumani) seeds per hill were planted in rows with a spacing of $75 \mathrm{~cm}$ between rows and $30 \mathrm{~cm}$ between maize hills. Watering was done after every seven days to allow for luxuriant growth of maize foliage. All other agronomic practices including hand pulling of weeds and hoeing were done uniformly for all the treatments.
TABle 1: Minimum temperature and rainfall data at Nyangati study site in Mwea subcounty, Kenya.

\begin{tabular}{lcc}
\hline Month & Minimum temperature $\left({ }^{\circ} \mathrm{C}\right)$ & Average rainfall $(\mathrm{mm})$ \\
\hline October & 14.6 & 51.5 \\
November & 15.5 & 100.1 \\
December & 14.7 & 109.2 \\
January & 13.6 & 46.5 \\
February & 21.6 & 21.6 \\
March & 12.0 & 33 \\
April & 14.0 & 32 \\
\hline
\end{tabular}

TABLe 2: Soil physicochemical characteristics at Nyangati study site in Mwea subcounty, Kenya.

\begin{tabular}{lcc}
\hline Soil property & Mean & Standard error \\
\hline Soil pH & 5.85 & 0.057 \\
Total nitrogen (\%) & 0.18 & 0.003 \\
Total organic carbon (\%) & 2.03 & 0.050 \\
Phosphorus (ppm) & 16.67 & 1.667 \\
Potassium (me\%) & 0.75 & 0.096 \\
Calcium (me\%) & 6.07 & 0.788 \\
Magnesium (me\%) & 3.63 & 0.135 \\
Manganese (me\%) & 0.97 & 0.114 \\
Copper (ppm) & 2.95 & 0.090 \\
Iron (ppm) & 23.50 & 3.239 \\
Zinc (ppm) & 0.20 & 0.029 \\
Sodium (me\%) & 0.16 & 0.074 \\
Sand (\%) & 46.67 & 3.712 \\
Clay (\%) & 44.00 & 4.000 \\
Silt (\%) & 9.33 & 0.667 \\
\hline
\end{tabular}

2.3. Sampling and Data Collection. Data were taken before planting (0 days) and 30, 60, and 90 days after planting. Plant data were recorded from five randomly selected plants per plot. In particular, leaf area index (LAI), plant height (PHt), number of functional leaves per plant (NoLP), main ear height, and grain yields were recorded. Leaf area index was estimated through digital hemispherical photography using a smartphone application (VitiCanopy) [19]. Plant height $(\mathrm{cm})$ was assessed from the base of the plant to the highest point of the arch of the uppermost leaf whose tip was pointing down, while ear height was assessed from the base of the plant to the main ear using a tape measure graduated in centimeter. The number of functional leaves in each plant was evaluated by a visual count of the green leaves using the leaf collar method [20]. The LAI, PHt, and NoLP were recorded at 30,60, and 90 days after planting while the main ear height was recorded at 60 and 90 days after planting. After 90 days, the grain yield in tons per hectare $(t / h a)$ was computed from randomly selected cobs using a weighing balance [21]. The grain yield obtained per plot was adjusted at $12.5 \%$ moisture content as described by Badu-Apraku et al. [22] as follows:

yield (at $12.5 \%$ grain moisture)

$$
=\text { grain yield } \times \frac{100-\text { actual grain moisture } \%}{87.5} \text {. }
$$


Soil samples were taken at preplanting (0 days), 30 days, 60 days, and at maturity (90 days). Five soil subsamples per plot, each measuring $100 \mathrm{~g}$, were collected randomly using an auger of diameter $3.5 \mathrm{~cm}$, at a depth of $0-20 \mathrm{~cm}$ using a cross diagonal sampling pattern. The subsamples were then bulked into a $500 \mathrm{~g}$ composite sample for each plot and placed in well-labeled plastic bags and sealed [23].

2.4. Weather Data and Soil Physicochemical Property Analysis. Minimum temperature and average rainfall data were obtained from the Kenya Meteorological Department, Nairobi, Kenya. Soil pH, total nitrogen, total organic carbon, phosphorus, calcium, magnesium, manganese, copper, iron, zinc, sodium, sand, clay, and silt were evaluated at the Kenya Agriculture and Livestock Research Organization, Kenya.

2.5. Nematode Extraction and Identification. Nematodes were extracted from $250 \mathrm{~g}$ soil samples derived from $500 \mathrm{~g}$ composite sample using the modified Baermann technique [24]. After extraction, $10 \mathrm{ml}$ of nematode suspension was fixed by adding an equal volume of fixative (golden solution) which was prepared as described by Hooper et al. [24]. The nematodes were counted from subaliquots of the extraction under DM750 Leica compound microscope and densities computed as described in [23]. Subsequently, nematodes were identified to genus level based on their morphological characteristics.

2.6. Data Analysis. To explore statistical differences in leaf area index (LAI), plant height, number of leaves per plant, ear height, grain yield, and abundance of Scutellonema, data were subjected to ANOVA test using package vegan in $\mathrm{R}$ software [25]. In order to meet the assumptions of statistical analysis, transformation of data was done where necessary prior to data analysis. The treatment means separation was implemented by the Tukey HSD test using package agricolae [26]. To investigate how LAI, plant height, and number of leaves per plant relate to Scutellonema abundance, Pearson correlation analysis was performed using the package ggpubr [27].

\section{Results}

In the current study, the data collected during the two trials revealed that leaf area index (LAI) did not differ significantly between MPWN treatments and the control plots treated with nematicide. The lowest value of LAI $(1.43 \pm 0.230)$ was recorded from MPWN in 2018, whereas during 2019, the highest value $(1.66 \pm 0.299)$ was observed in MPWN. Data pertaining to the plant height clearly showed a significant difference between MPWN relative to the control during 2018-2019. The minimum plant height was recorded in MPWN ranged between $112.11 \pm 22.249$ and $92.55 \pm 21.220$ in $\mathrm{cm}$ during the two trials. Similarly, the lowest number of leaves per plant ranging between $6.66 \pm 1.082$ and $7.44 \pm 1.260$ in $\mathrm{cm}$ was recorded in MPWN treatments in both trials. The mean ear height in maize plants for
2018-2019 was lower in MPWN, although the data for 2018 were not statistically different at $p=0.255$. Additionally, the lowest grain yields (t/ha) during 2018-2019 were also observed in MPWN, but the yield data for 2018 were not significantly different at $p=0.528$. The abundance of Scutellonema was low in MPWN in trial one (2018), whereas during 2019 it was higher in MPWN, but there was no significant difference in Scutellonema abundance in 2018 $(p=0.634)$ and $2019(p=0.277)$ data. Overall, MPWN treatments showed relatively lower measures of plant height, number of functional leaves per plant, mean ear height, and grain yields compared to control amended with nematicide (Table 3).

Further analyses revealed that leaf area index (LAI), plant height, and the number of leaves per plant were positively increased but weakly correlated with Scutellonema density in MPWN at $R \leq 0.37$ during trial one (2018), and the correlation was not statistically different $(p>0.05)$ (Table 4 and Figures 1(a), 2(a), and 3(a)). However, during the second trial (2019), MPWN showed a significant negative correlation between LAI, plant height, and the number of functional leaves per plant with the Scutellonema abundance at $R \geq-0.52$ and $p<0.05$ (Table 4 and Figures $1(\mathrm{~b}), 2(\mathrm{~b})$, and $3(b))$. For the control plots, during trial one (2018), the relationship between Scutellonema population and LAI, plant height, and the number of functional leaves was negative at $R \geq-0.93$ and $p<0.001$ (Table 4 and Figures 4(a), 5(a), and 6(a)), while for the second trial (2019), it was negatively correlated for plant height and number of leaves $(R \geq-0.31, p>0.05)$, but for LAI it was positively correlated at $R=0.65$ and $p=0.0060$ (Table 4 and Figures 4(b), 5(b), and $6(\mathrm{~b}))$.

\section{Discussion}

The current study was carried out to evaluate maize performance, as provided by different parameters, in a field infested with Scutellonema spp. Leaf area index (LAI) is an important plant characteristic which may affect plant productivity and is a significant indicator of plant growth, grain yield, and biomass production [21]. It also relates to the ability of the maize canopy to absorb sunlight and fix carbon. In comparison with an ideal maize LAI of 3.5 to 4.0 which indicates efficient sunlight absorption [28], our LAI values ranged between $1.43 \pm 0.230$ and $1.66 \pm 0.299$. This implies that the maize plants in both MPWN and control treatments absorbed a minimal amount of solar radiation. Previous findings have concluded that leaf area index is a determinant of yield loss due to damage by nematodes [29]. In this study, the lowest and highest value of LAI in MPWN clearly corresponded with the lowest and highest density of Scutellonema abundance for 2018 and 2019, respectively, although they were not statistically different. In addition, during 2019, the correlation analysis showed a significant negative relationship between LAI and Scutellonema density in MPWN. These results collaborate the findings reported by Roderick et al. [30] and Tripathi et al. [29], who noted a significant correlation between the density of Radopholus 
TABLE 3: Leaf area index (LAI), plant height (PHt), number of leaves per plant (NoLP), main ear height, grain yield, and Scutellonema density in control plots (treated with nematicide) and MPWN (maize plots with no nematicide) during trial one (2018) and trial two (2019) in Nyangati study site, Mwea subcounty.

\begin{tabular}{|c|c|c|c|c|c|}
\hline Parameter & Year & $\begin{array}{c}\text { Control } \\
\text { Mean } \pm \text { SE }\end{array}$ & $\begin{array}{c}\text { MPWN } \\
\text { Mean } \pm \text { SE }\end{array}$ & $F$ value & $p$ value \\
\hline \multirow{2}{*}{ LAI } & 2018 & $1.51 \mathrm{a} \pm 0.243$ & $1.43 a \pm 0.230$ & 0.595 & 0.448 \\
\hline & 2019 & $1.65 a \pm 0.391$ & $1.66 a \pm 0.299$ & 3.619 & 0.069 \\
\hline \multirow{2}{*}{ PHt (cm) } & 2018 & $114.05 \mathrm{a} \pm 21.988$ & $112.11 b \pm 22.249$ & 4.649 & $0.041^{*}$ \\
\hline & 2019 & $112.30 \mathrm{a} \pm 25.569$ & $92.55 b \pm 21.220$ & 168.135 & $<0.001^{* * *}$ \\
\hline \multirow{2}{*}{ NoLP } & 2018 & $7.15 \mathrm{a} \pm 1.176$ & $6.66 \mathrm{~b} \pm 1.082$ & 18.909 & $<0.001^{* * *}$ \\
\hline & 2019 & $8.20 \mathrm{a} \pm 1.402$ & $7.44 \mathrm{~b} \pm 1.260$ & 84.552 & $<0.001^{* * *}$ \\
\hline \multirow{2}{*}{ Ear height $(\mathrm{cm})$} & 2018 & $82.80 \mathrm{a} \pm 4.384$ & $79.98 \mathrm{a} \pm 1.768$ & 1.428 & 0.255 \\
\hline & 2019 & $94.60 \mathrm{a} \pm 1.133$ & $71.05 b \pm 3.928$ & 48.203 & $<0.001^{* * *}$ \\
\hline \multirow{2}{*}{ Grain yield (t/ha) } & 2018 & $3.83 a \pm 0.000$ & $3.53 a \pm 0.446$ & 0.448 & 0.528 \\
\hline & 2019 & $2.99 \mathrm{a} \pm 0.000$ & $2.28 b \pm 0.0713$ & 99.249 & $<0.001^{* * *}$ \\
\hline \multirow{2}{*}{ Scutellonema } & 2018 & $71.50 \mathrm{a} \pm 14.727$ & $67.44 \mathrm{a} \pm 13.542$ & 0.233 & 0.634 \\
\hline & 2019 & $113.75 \mathrm{a} \pm 13.295$ & $153.563 \mathrm{a} \pm 42.528$ & 1.239 & 0.277 \\
\hline
\end{tabular}

Means within the same row followed by the same letters are not significantly different. ${ }^{* * *} p<0.001,{ }^{* *} p<0.01$, and ${ }^{*} p<0.05$.

TABLE 4: Relationship between Scutellonema abundance, maize leaf area index (LAI), plant height (PHt), and number of leaves per plant (NoLP) in control plots (treated with nematicide) and MPWN (maize plots with no nematicide) during trial one (2018) and two (2019) at Nyangati study site, Mwea subcounty.

\begin{tabular}{|c|c|c|c|c|}
\hline Treatment & Relationship & R-value & $p$ value & $\mathrm{df}$ \\
\hline \multicolumn{5}{|l|}{ Trial one } \\
\hline & Scutellonema vs. LAI & -0.98 & $<0.001^{* * *}$ & 14 \\
\hline \multirow[t]{3}{*}{ Control } & Scutellonema vs. PHt & -0.98 & $<0.001^{* * *}$ & 14 \\
\hline & Scutellonema vs. NoLP & -0.93 & $<0.001^{* * *}$ & 14 \\
\hline & Scutellonema vs. LAI & 0.37 & 0.155 & 14 \\
\hline \multirow[t]{2}{*}{ MPWN } & Scutellonema vs. PHt & 0.09 & 0.755 & 14 \\
\hline & Scutellonema vs. NoLP & 0.01 & 0.974 & 14 \\
\hline \multicolumn{5}{|l|}{ Trial two } \\
\hline \multirow{3}{*}{ Control } & Scutellonema vs. LAI & 0.65 & $0.006^{* *}$ & 14 \\
\hline & Scutellonema vs. PHt & -0.49 & 0.052 & 14 \\
\hline & Scutellonema vs. NoLP & -0.31 & 0.248 & 14 \\
\hline \multirow{3}{*}{ MPWN } & Scutellonema vs. LAI & -0.54 & $0.032^{*}$ & 14 \\
\hline & Scutellonema vs. PHt & -0.52 & $0.038^{*}$ & 14 \\
\hline & Scutellonema vs. NoLP & -0.71 & $0.002^{* *}$ & 14 \\
\hline
\end{tabular}

${ }^{*} \mathrm{~d} f=$ degrees of freedom. ${ }^{* * *} p<0.001,{ }^{* *} p<0.01$, and ${ }^{*} p<005$.

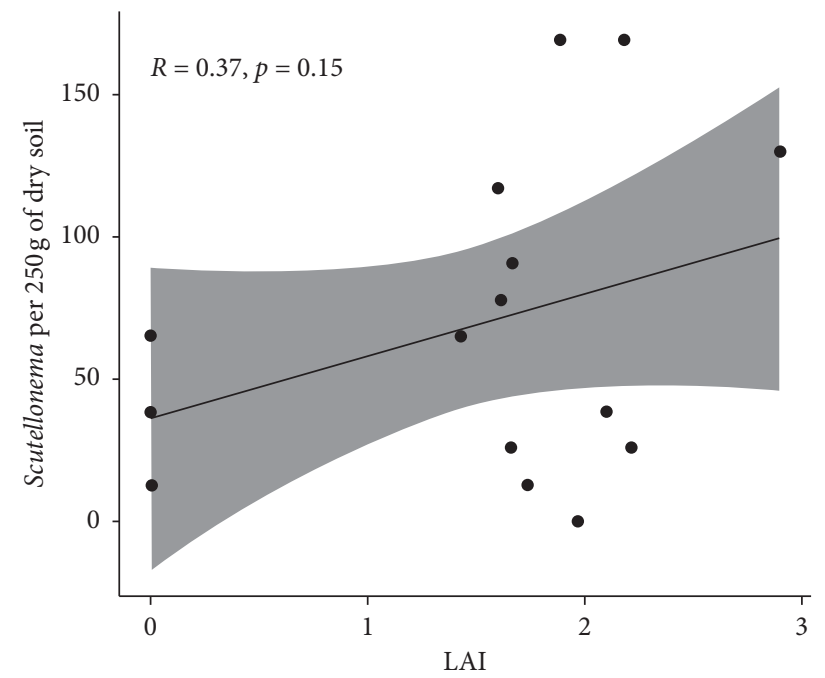

(a)

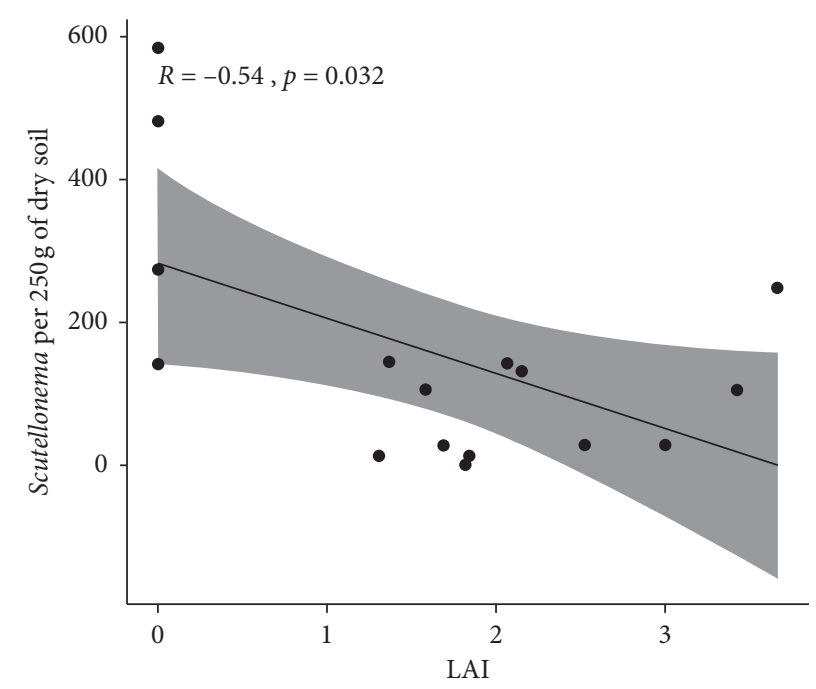

(b)

FigURE 1: Correlation between leaf are index (LAI) and Scutellonema abundance during trial one in 2018 (a) and trial two in 2019 (b) in MPWN treatments. The relationship for 2018 revealed a nonsignificant positive association $(R=0.37, p=0.15)$, while that for 2019 revealed a negative association $(R=-0.54, p=0.032)$. 


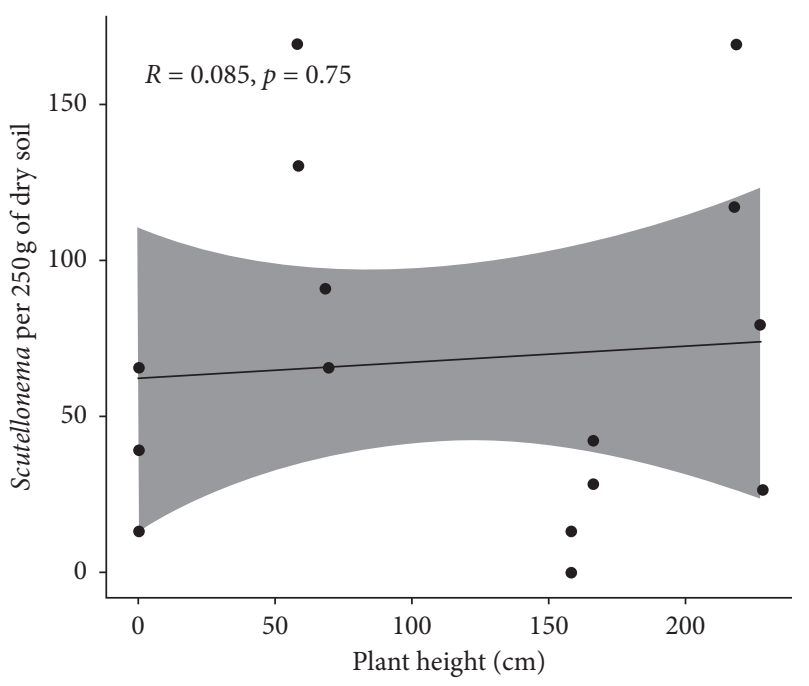

(a)

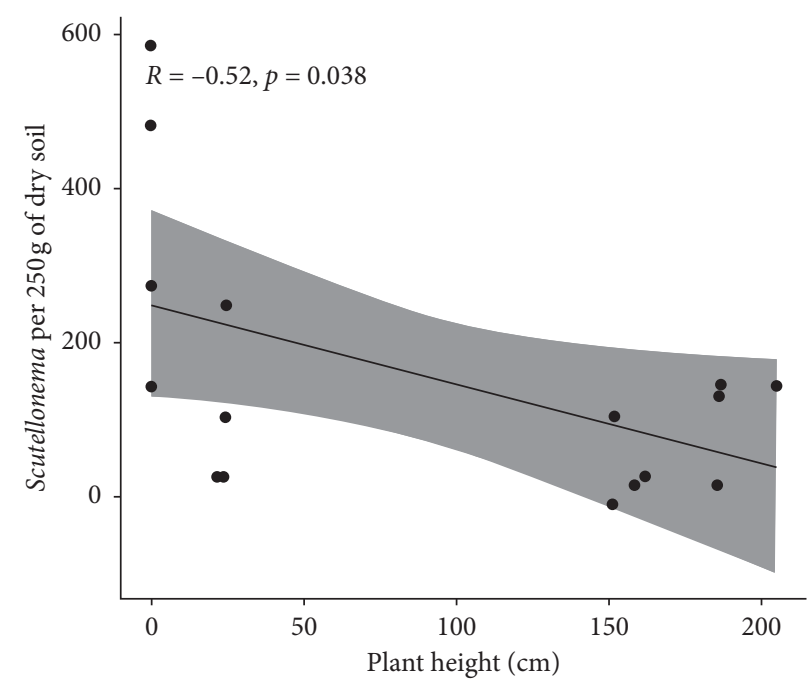

(b)

FIgURe 2: Correlation between plant height and Scutellonema abundance during trial one in 2018 (a) and trial two in 2019 (b) in MPWN treatments. The relationship for 2018 revealed a weak positive association $(R=0.085, p=0.75)$, whereas for 2019 it was significantly negative $(R=-0.52, p=0.038)$.

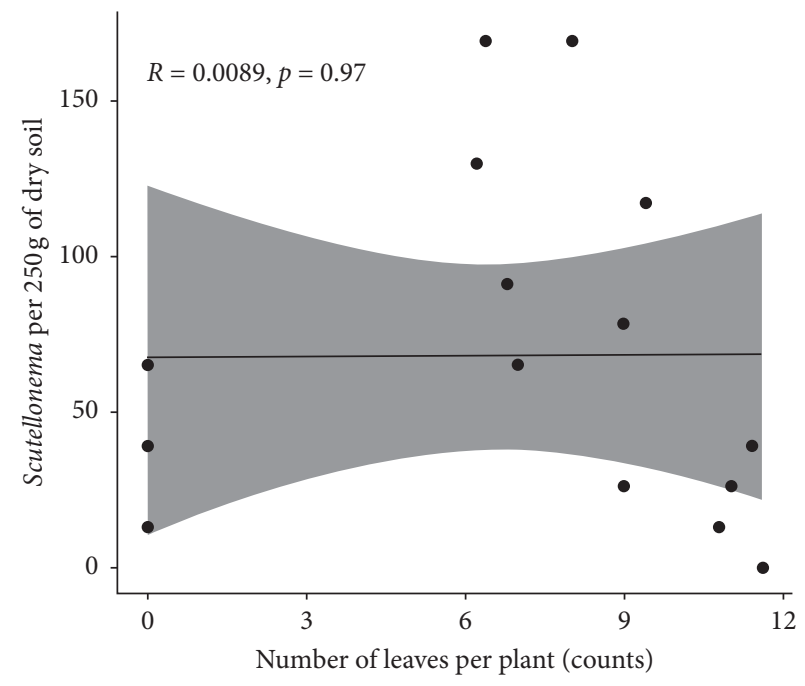

(a)

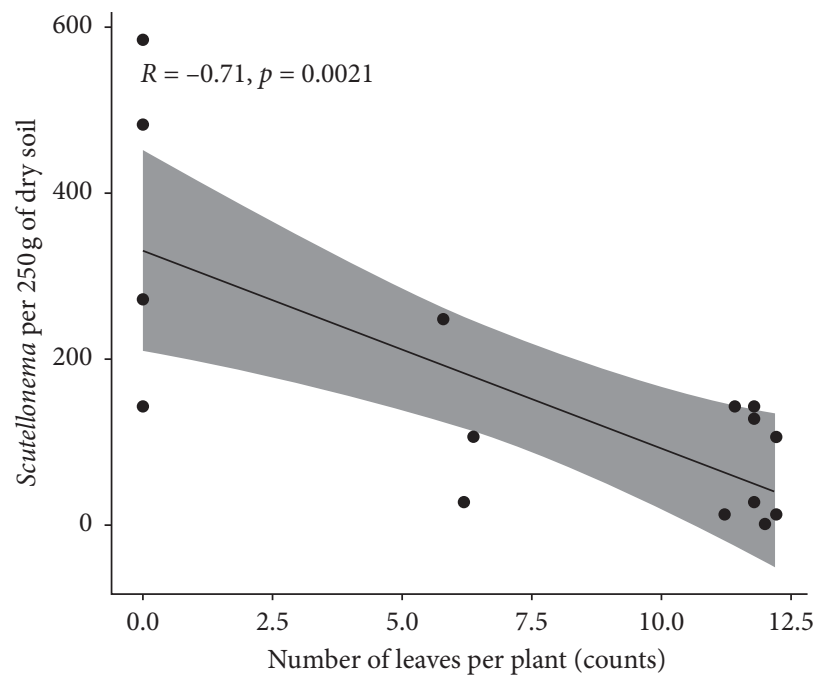

(b)

Figure 3: Correlation between number of leaves per plant and Scutellonema abundance during 2018 (a) and 2019 (b) in MPWN treatments. The association for 2018 revealed a very weak positive nonsignificant association $(R=0.01, p=0.97)$, whereas for 2019 it was negative $(R=-0.71, p \leq 0.01)$.

similis and Helicotylenchus multicinctus and a reduction in LAI.

Crop height is used to project crop yield, biomass production, and plant growth [31]. In our findings, the minimum maize height correlated to the lowest yields in MPWN in both trials. Similar results were found by Yin et al. [32], who noted that monitoring the development of maize plant height at various growth stage intervals is a very useful indicator of the potential yields. Assessment of main ear height provides useful information that can be used in breeding maize. The ideal main ear height should be neither too high nor too low [33]. Our findings showed that maize plants in MPWN exhibited not only lower plant height but also lower ear height compared to control. The difference in these results may be associated with the use of nematicides which have been reported to improve crop growth through plant-parasitic nematodes suppression $[34,35]$, and alleviation of zinc deficiency symptoms [36]. Grain yield being an ultimate outcome of photosynthesis through various integrated physiological processes of the plant is affected by environmental variables, biotic and abiotic constraints [37]. In addition, it is an important measure of plant growth as it reflects the relative growth rate as net assimilation rate [38]. The lowest grain yield in this study correlated with lower Scutellonema density during the 2018 trial in MPWN although both grain yield and Scutellonema abundance data 


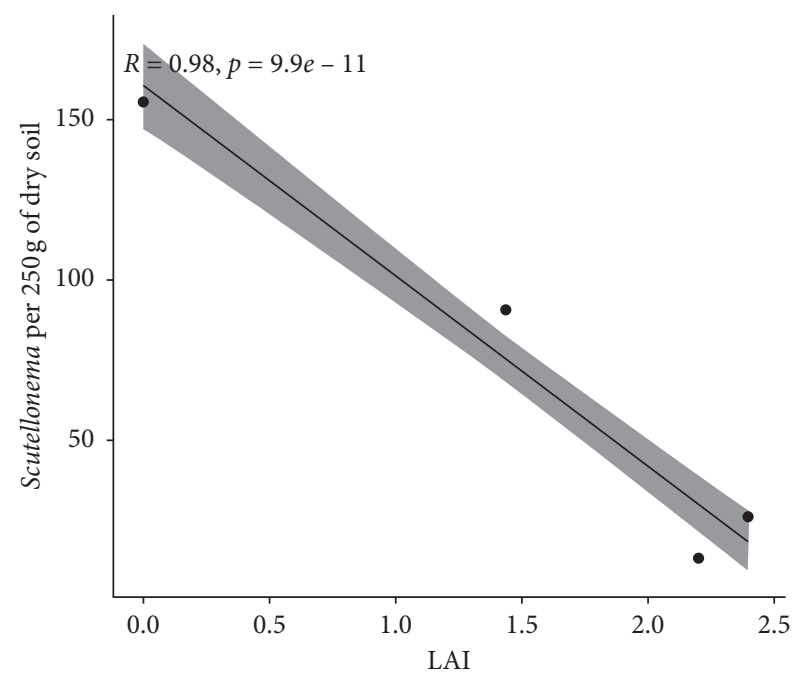

(a)

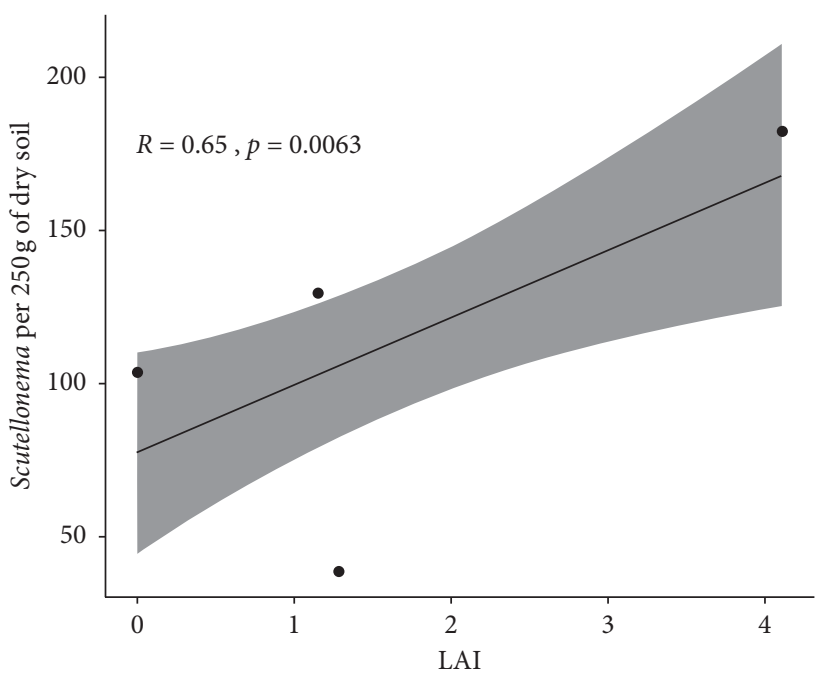

(b)

Figure 4: Correlation between leaf area index (LAI) and Scutellonema density during 2018 (a) and 2019 (b) in control plots. The relationship for 2018 showed a significant negative association $(R=-0.98, p \leq 0.001)$, while for 2019 it was positive $(R=0.65, p<0.05)$.

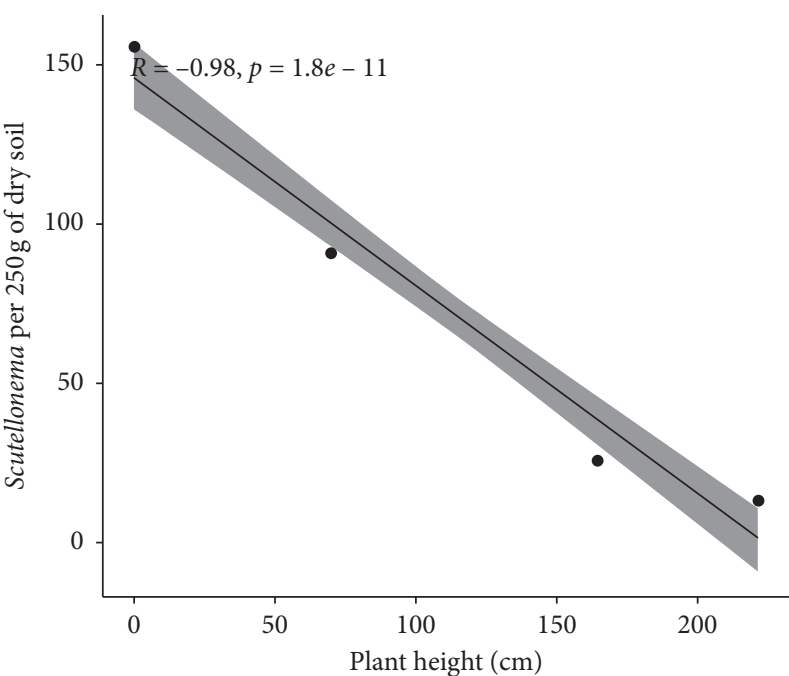

(a)

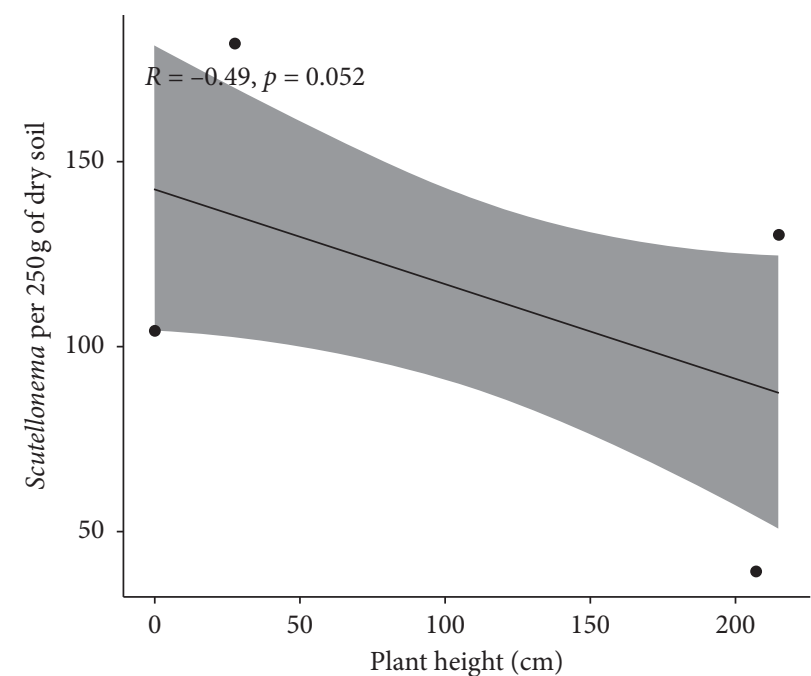

(b)

Figure 5: Correlation between plant height and Scutellonema density during 2018 (a) and 2019 (b) in control plots. The relationship for 2018 and 2019 showed a significant negative association $(R=-0.98, p \leq 0.001$, and $R=-0.49, p=0.052$, respectively).

were not significantly different relative to the control. In contrast, during 2019, lower significant yields in MPWN were correlated to a higher population of Scutellonema, whose abundance was not statistically different compared to the control. These observations imply that it is often complex under field conditions to quantitatively link nematode population abundances with yield loss since nematodes closely interact with other factors including nutrient availability, water, and other secondary pathogens such as fungi and bacteria which may exacerbate the situation $[5,39,40]$. Moreover, the correlation analysis between plant height and the population density of Scutellonema revealed a significant negative relationship in MPWN (2019), while in 2018 the association was not significant. This, therefore, suggests that Scutellonema abundance could probably have affected maize plant height negatively in MPWN under natural infestation where lower plant height was noted. High density of spiral nematodes, Helicotylenchus spp., was correlated with reductions of plant height, root masses, and chlorophyll content in maize fields in India [41]. Elsewhere, plant-feeding nematodes particularly root-lesion nematodes have been found to cause significant reduction in plant height in maize fields through impaired root systems, thereby causing stunted growth and yield loss [5, 42, 43].

The increase or decline in the number of functional leaves in each plant has a significant impact on the crop yields [21]. Leaves are important plant organs through which plants interact with the external environment and they are 


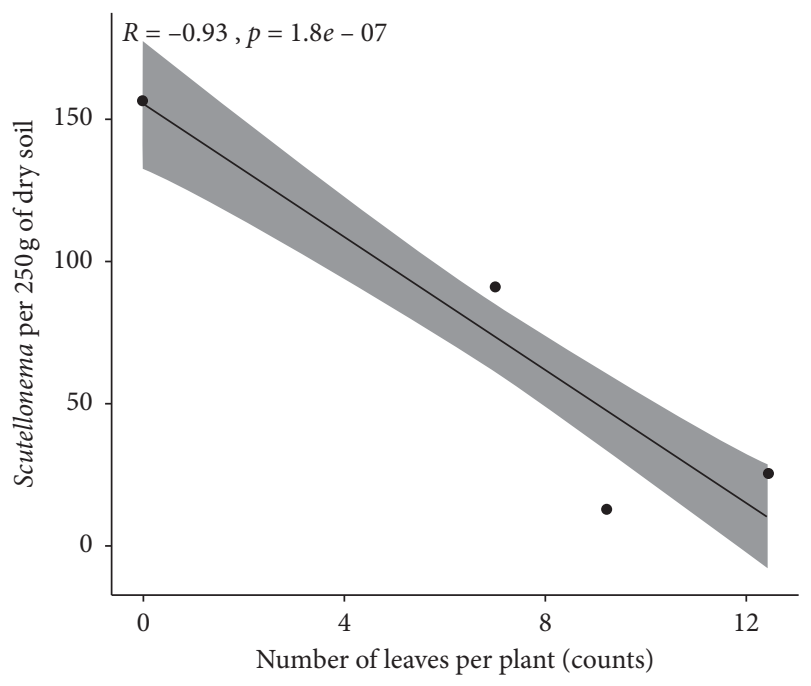

(a)

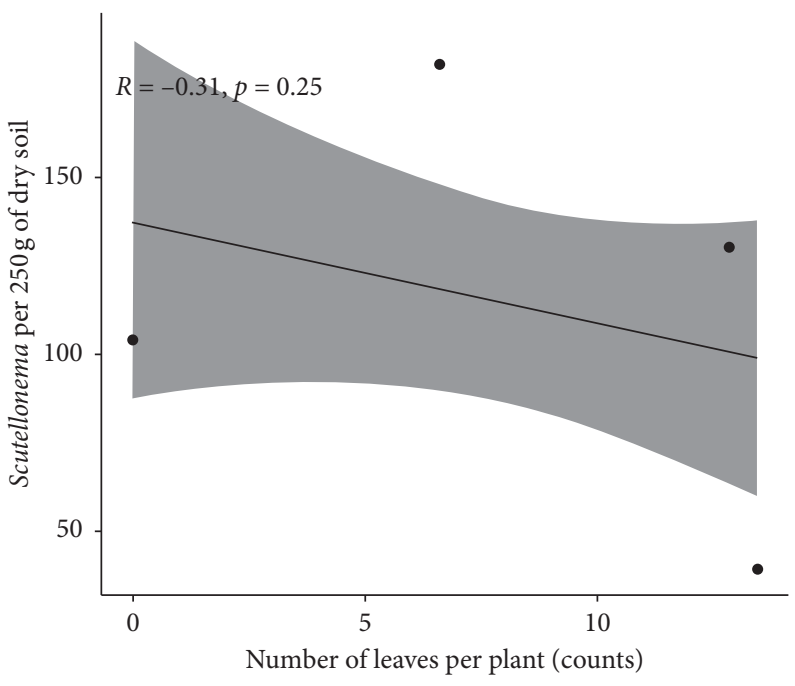

(b)

Figure 6: Correlation between number of leaves per plant and Scutellonema density during 2018 (a) and 2019 (b) in control plots. The relationship for 2018 showed a significant negative association $(R=-0.93, p \leq 0.001)$, while for 2019 it was nonsignificant $(R=-0.31$, $p=0.25$ ).

sites for photosynthesis. The lower number of leaves in this study was in parallel with lower yields recorded in MPWN treatments during both trials, but the yields for 2018 were not statistically different. Additionally, a significant negative association between the number of leaves per plant with Scutellonema density was observed in 2019, whereas the relationship for 2018 was not statistically different. This may be explained by the fact that Scutellonema spp. attack plant roots ectoparasitically and then invade the deeper cortical layers, resulting in reduction in the efficiency of root systems to uptake water and nutrients [14]. The damage in plant roots caused by Scutellonema spp. influences the translocation of photosynthates from the leaves to infected root tissues while in turn leaves will also experience a shortage of water, minerals, and nutrients [15]. Due to poor supply of water and nutrients, the development of leaf tissues and chlorophyll pigments is strongly affected [41, 44], consequently reducing the number of functional leaves per plant leading to lower yields.

\section{Conclusion}

This study provides an insight on the impacts of Scutellonema spp. density on maize plants in Mwea subcounty under natural field infestation. The high population of Scutellonema spp. has the potential to negatively affect maize leaf area index, plant height, number of functional leaves per plant, and grain yields. This information will be useful in implementing reliable and timely interventions that will ensure optimal maize production. Based on this, we recommend that holistic sustainable management practices against Scutellonema spp. in maize fields such as use of organic amendments, resistant maize cultivars, and antagonistic organisms are put in place in order to mitigate potential losses.

\section{Data Availability}

The data used to support the findings of this study are available from the corresponding author upon request.

\section{Conflicts of Interest}

The authors declare that there are no conflicts of interest regarding the publication of this paper.

\section{Acknowledgments}

This work was supported by the Department for International Development under the Climate Impact Research Capacity and Leadership Enhancement programme as part of research uptake fund.

\section{References}

[1] C. Short, W. Mulinge, and M. Witwer, Analysis of Incentives and Disincentives for Maize in KenyaTechnical Notes Series, MAFAP, FAO, Italy, Rome, 2012.

[2] Ministry of Agriculture, Economic Review of Agriculture [ERA] 2015. Central Planning and Monitoring Unit, MoA, Ministry of Agriculture, Nairobi, Kenya, 2015.

[3] FAOSTAT, Production/Yield Quantities of Maize in Kenya 2010-2019, FAOSTAT, Italy, Rome, 2019, http://www.fao.org/ faostat/en/\#data/QC/visualize.

[4] H. Macauley and T. Ramadjita, "Cereal crops: rice, maize, millet, sorghum, wheat," in Proceedings of the Feeding Africa. Abdou Diouf International Conference Center, pp. 1-36, Dakar, Senegal, October 2015.

[5] A. H. McDonald and J. M. Nicol, "Nematode parasites of cereals," in Plant Parasitic Nematodes in Subtropical and Tropical Agriculture, M. Luc, R. A. Sikora, and J. Bridge, Eds., pp. 131-192, CAB International, Wallingford, UK, 2005. 
[6] J. W. Waceke, O. J. Arim, S. W. Waudo, and J. W. Kimenju, "Plant-parasitic nematodes of maize (Zea mays L.) in low input agriculture in Kenya," African Crop Science Journal, vol. 8, no. 5, pp. 443-450, 2013.

[7] A. H. Mc Donald, D. De Waele, and H. Fourie, "Nematode pests of maize and other cereal crops," in Nematology in South Africa: A View from the 21st Century, H. Fourie, V. W. Spaull, R. K. Jones, M. S. Daneel, and D. De Waele, Eds., pp. 183-199, Springer, Cham, Switzerland, 2017.

[8] A. Viña, A. A. Gitelson, D. C. Rundquist, G. Keydan, B. Leavitt, and J. Schepers, "Monitoring maize (Zea mays L.) phenology with remote sensing," Agronomy Journal, vol. 96, no. 4, pp. 1139-1147, 2004.

[9] D. A. Wardle, R. D. Bardgett, J. N. Klironomos, H. Setälä, W. H. Van Der Putten, and D. H. Wall, "Ecological linkages between aboveground and belowground biota," Science, vol. 304, no. 5677, pp. 1629-1633, 2004.

[10] R. D. Bardgett and W. H. Van Der Putten, "Belowground biodiversity and ecosystem functioning," Nature, vol. 515, no. 7528, pp. 505-511, 2014.

[11] M. A. Bradford, T. H. Jones, R. D. Bardgett et al., "Impacts of soil faunal community composition on model grassland ecosystems," Science, vol. 298, no. 5593, pp. 615-618, 2002.

[12] T. Bezemer and N. Vandam, "Linking aboveground and belowground interactions via induced plant defenses," Trends in Ecology \& Evolution, vol. 20, no. 11, pp. 617-624, 2005.

[13] C. Wagg, S. F. Bender, F. Widmer, and M. G. A. van der Heijden, "Soil biodiversity and soil community composition determine ecosystem multifunctionality," Proceedings of the National Academy of Sciences, vol. 111, no. 14, pp. 5266-5270, 2014.

[14] J. Bridge, "Priorities in plant nematology, a national and regional review," in Crop Protection and the Kenya Smallholder Farmer, J. A. Sutherland, Ed., pp. 22-24, National Agricultural Research Laboratories, Nairobi, Kenya, 1994.

[15] J. Bridge and J. Starr, Plant Nematodes of Agricultural Importance: A Colour Handbook, Manson Publishing Ltd., London, UK, 2007.

[16] J. M. Nicol, S. J. Turner, D. L. Coyne, L. Den Nijs, S. Hockland, and Z. T. Maafi, "Current nematode threats to world agriculture," in Genomics and Molecular Genetics of PlantNematode Interactions, G. Gheysen and C. Fenoll, Eds., pp. 21-43, Springer, Berlin, Germany, 2011.

[17] D. L. Coyne, L. Cortada, J. J. Dalzell et al., "Plant-parasitic nematodes and food security in Sub-Saharan Africa," Annual Review of Phytopathology, vol. 56, no. 1, pp. 381-403, 2018.

[18] R. Jaetzold, H. Schmidt, B. Hornetz, and C. Shisanya, "Farm management handbook of Kenya VOL. II-Natural conditions and farm management information," in ANNEX: Atlas of Agro-Ecological Zones, Soils and Fertilising by Group of Districts. Subpart B1a: Southern Rift Valley Province, Ministry of Agriculture, Kenya and Cooperation with the German Agency for Technical Cooperation (GTZ), Nairobi, Kenya, 2009.

[19] R. De Bei, S. Fuentes, M. Gilliham et al., "VitiCanopy: a free computer App to estimate canopy vigor and porosity for grapevine," Sensors, vol. 16, no. 4, p. 585, 2016.

[20] R. L. B. Nielsen, "Determining Corn Leaf Stages," Corny News Network Articles, p. 237, Purdue University, West Lafayette, IN, USA, 2003.

[21] F. Laekemaria and G. Gidago, "Growth and yield response of maize (Zea mays L.) to variable rates of compost and inorganic fertilizer integration in Wolaita, Southern Ethiopia," American Journal of Plant Nutrition and Fertilization Technology, vol. 3, no. 2, pp. 43-52, 2013.
[22] B. F. Badu-Apraku, M. A. Menkir, and D. Sanogo, Conduct and Management of Maize Field Trials, p. 59, International Institute of Tropical Agriculture (IITA), Ibadan, Nigeria, 2012.

[23] D. L. Coyne, J. M. Nicol, and B. Claudius-Cole, Practical Plant Nematology: A Field and Laboratory Guidep. 82, 2nd edition, International Institute of Tropical Agriculture (IITA), Ibadan, Nigeria, 2014.

[24] D. J. Hooper, J. Hallmann, and S. A. Subbotin, "Methods for extraction, processing and detection of plant and soil nematodes," in Plant Parasitic Nematodes in Subtropical and Tropical Agriculture, M. Luc, R. A. Sikora, and J. Bridge, Eds., pp. 53-86, CAB International, Wallingford, UK, 2005.

[25] R Development Core Team, R: A Language and Environment for Statistical Computing, $\mathrm{R}$ Foundation for Statistical Computing, Vienna, Austria, 2015.

[26] F. De Mendiburu, Agricolae: Statistical Procedures for Agricultural Research. R Package Version 1.2-3, R Foundation for Statistical Computing, Vienna, Austria, 2015.

[27] A. Kassambara, ggpubr: "ggplot2" Based Publication Ready Plots. R Package Version 0.1. 8, R Foundation for Statistical Computing, Vienna, Austria, 2018.

[28] E. Nafziger, "Corn," in Service, Illinois Agronomy Handbook, Ed., University of Illinois at Urbana-Champaign, College of Agriculture, Cooperative Extension Service, Urbana, IL, USA, 24th edition, 2008.

[29] L. Tripathi, A. Babirye, H. Roderick et al., "Field resistance of transgenic plantain to nematodes has potential for future African food security," Scientific Reports, vol. 5, p. 8127, 2015.

[30] H. Roderick, E. Mbiru, D. Coyne, L. Tripathi, and H. J. Atkinson, "Quantitative digital imaging of banana growth suppression by plant parasitic nematodes," PLoS One, vol. 7, no. 12, Article ID e53355, 2012.

[31] G. J. Grenzdörffer, "Crop height determination with UAS point clouds," International Archives of the Photogrammetry, Remote Sensing and Spatial Information Sciences, vol. XL-1, p. 135, 2014.

[32] X. Yin, M. A. McClure, N. Jaja, D. D. Tyler, and R. M. Hayes, "In-season prediction of corn yield using plant height under major production systems," Agronomy Journal, vol. 103, no. 3 , pp. 923-929, 2011.

[33] C. Szőke, "Inheritance of plant and ear height in maize (Zea mays L.)," Acta Agraria Debreceniensis, vol. 8, pp. 34-38, 2002.

[34] D. C. Norton and P. Hinz, "Relationship of Hoplolaimus galeatus and Pratylenchus hexincisus to reduction of corn yields in sandy soils in Iowa [Nematodes]," Plant Disease Reporter, vol. 60, pp. 197-200, 1976.

[35] T. C. Todd and T. R. Oakley, "Seasonal dynamics and yield relationships of Pratylenchus spp. in corn roots," Journal of Nematology, vol. 28, no. 4S, pp. 676-681, 1996.

[36] N. A. Minton, M. B. Parker, and D. R. Sumner, "Nematode control related to Fusarium wilt in soybean and root rot and zinc deficiency in corn," Journal of Nematology, vol. 17, no. 3, pp. 314-21, 1985.

[37] M. Abid, Z. Tian, S. T. Ata-Ul-Karim et al., "Adaptation to and recovery from drought stress at vegetative stages in wheat (Triticum aestivum) cultivars," Functional Plant Biology, vol. 43, no. 12, pp. 1159-1169, 2016.

[38] H. Z. Khan, M. A. Malik, and M. F. Saleem, "Effect of rate and source of organic material on the production potential of spring maize (Zea mays L.)," Pakistan Journal of Agricultural Sciences, vol. 45, no. 1, pp. 40-43, 2008.

[39] G. N. Agrios, Plant Pathology, pp. 79-103, Elsevier Academic Press, Burlington, NJ, USA, 5th edition, 2005. 
[40] R. A. Sikora, D. Coyne, J. Hallmann, and P. Timper, Plant Parasitic Nematodes in Subtropical and Tropical Agriculture, CAB International Wallingford, Oxfordshire, UK, 2018.

[41] D. Kumar and U. S. Singh, "Pathogenicity of spiral nematode, Helicotylenchus indicus and effect on chlorophyll content of maize," Indian Journal of Nematology, vol. 37, no. 1, pp. 101-102, 2007.

[42] D. C. Norton, "Maize nematode problems," Plant Disease, vol. 67, no. 3, pp. 253-256, 1983.

[43] G. L. Tylka, T. C. Todd, T. L. Niblack, A. E. MacGuidwin, and T. Jackson, "Sampling for plant-parasitic nematodes in corn strip trials comparing nematode management products," Plant Health Progress, vol. 12, no. 1, p. 28, 2011.

[44] M. R. Khan and M. W. Khan, "Effects of the root-knot nematode, Meloidogyne incognita, on the sensitivity of tomato to sulfur dioxide and ozone," Environmental and Experimental Botany, vol. 38, no. 2, pp. 117-130, 1997. 